\title{
Viability of a terrace covered with porous concrete paving blocks for coffee bean drying
}

João Pedro Junqueira ${ }^{1}$

Alisson Pinto Soares Ponzo 2

Alisson Souza de Oliveira ${ }^{3}$

\section{Abstract}

The success of the coffee activity depends on the beans drying process since it influences the physical and chemical coffee quality, whose result can be good or bad quality beverages. In this sense, the type of terrace has considerable influence on the product's final quality. Therefore, in this study, ground soil terraces and porous concrete paving blocks will be evaluated, and the experiment was conducted in the city of Cambuquira/MG. For this purpose, porous concrete and compressed earth blocks with dimensions of $50 \mathrm{~cm} \times 50 \mathrm{~cm} \times 10 \mathrm{~cm}$ were built, totaling 10 blocks of each type of terrace. The experimental design was in randomized blocks (RB), using cherry coffee, with 10 replications, with a total of 20 plots. For the evaluation of the water infiltration capacity in the porous concrete paving block, a cylinder of $30 \mathrm{~cm}$ in diameter was used placed in the center of the porous concrete block, and the lower edges rejoined with cement to guarantee the use of the internal area of the cylinder only. The drying process of coffee on a porous concrete paving block terrace provided better quality both in the beverage and in the reduction of the number of defects in the beans. In the city of Cambuquira, the potential for infiltration and storage of rainwater is $58.8 \mathrm{~m}^{3}$ year- 1 . Considering a 10-year lifespan, the construction of the porous concrete paving block terrace is economically viable concerning the ground soil terrace, providing gains of up to $15 \%$.

Keywords: Coffee quality. Rainwater infiltration. Rain water.

\section{Introduction}

Brazil is a country that has favorable climatic conditions for the crop, providing planting from North to South, facing different climates, altitudes, soils, among others, making Brazilian producers achieve different quality standards and unique characteristics to their products.

The culture of coffee, since it was implanted in Brazil in the middle of the 17th century, has acquired considerable economic and social importance, becoming today the biggest exporter in the world scenario. In 2018, national production was approximately 58.04 million bags, representing $36 \%$ of the international market. In the state of Minas Gerais, especially in the southern region, coffee culture is one of the principal activities developed on rural properties. In 2018, coffee production in the state reached about 30.7 million bags, corresponding to approximately $53 \%$ of all national production (CONAB, 2018).

1 Universidade Vale do Rio Verde (UninCor). Graduando em Agronomia. joaopedrojunqueiracbq@hotmail.com. Av. Castelo Branco, 82 Chácara das Rosas, Três CoraçõesMG, 37417-150.

2 UninCor. Graduando em Agronomia. jonasponzo@yahoo.com.br

3 UninCor. Professor titular. alissonso@hotmail.com. 
There are several species of coffee, the main ones with economic viability produced in Brazil, the robusta (Coffea canephora), and the arabica (Coffea arabica). The Arabian species is the main cultivated and also the best known. According to COSTE (1955), arabica coffee has a main stem with secondary branches in which fruiting occurs, it is estimated a production of 34.30 million bags in 2019 (CONABE, 2018). The arabica coffee has a pleasant quality, aroma and flavor, and less pronounced caffeine content, making it the most wanted coffee in the market. It issues a quality seal for the producers, thus aiming at a quality of origin. The varieties Bourbon Amarelo, Bourbon Vermelho, Catuaí Amarelo, Catuaí Vermelho, Obatã, and Mundo Novo stand out.

Robusta coffee, known as conilon, is a species with higher resistance to the diversity exposed in Brazil, such as drought and precipitation. Its predominant production occurs in the state of Espírito Santo, north of Minas Gerais, and North of the Country. Robusta coffee does not have a main stem, but several branches in which fruiting occurs, it has higher levels of caffeine compared to Arabica (PAULINO et al., 1987). In addition to a unique flavor and less acidity, it has a much lower production cost, which makes it attractive for many producers who try to escape higher investment in maintaining the crop. However, its market value is also lower. Besides robust and arabica coffee, there is the blending, which can be defined as mixtures of two or more types of coffee that can be from the same species or from different species and also from different regions and crops (FERNANDES et al., 2003). The creation of the blending is the way to combine coffees with complementary characteristics, seeking a balance between body, acidity, sweetness, and degree of roasting in such a way that the mixture produces a beverage with specific characteristics for a particular type of consumer (MOURA et al., 2007).

The drying process of coffee is one of the steps that most influences the quality of the beans (SILVA, LACERDA FILHO, 1984). In Brazil, there is drying in mechanical dryers and in terraces, which are composed of various materials, the most used are: beaten earth, which material is the same soil where the coffee beans will be cleaned and compacted with a mechanical roller, sheepskin or manual socket; asphalt mud, which uses materials such as waterproofing, gravel powder, and asphalt emulsion for its manufacture; concrete, which uses for its production materials such as gravel, sand, and cement to make the concrete; suspended terrace, which can use wood from the farm for its production, such as posts, bamboo, and concrete beams to make the base where the shade cloth will be placed; paved terrace, which has a higher initial cost of implementation because it has a higher quantity of materials and labor (SANTOS; REINATO, 2017).

Some studies have been carried out to determine the physical and chemical impacts of paved and unpaved terraces on the final quality of the grains (VIANA et al., 2002; BORÉM et al., 2004; REINATO et al., 2005). These impacts affect the final classification and its quality, as grains with physical defects tend to have a lower price than a grain with normal characteristics. The grain with chemical changes in its constitution loses market price, presents unpleasant taste, astringency, aroma, acidity. That is due to the depreciation of sugar levels, increased electrical conductivity, and leaching of potassium, which reduces the sensory quality of coffee (MARQUES et al., 2008).

However, these chemical changes depend a lot on the pre and post-harvest, because grains with physical damage tend to be more intense, therefore, the pre-drying process, in other words, the harvest and transport of grains, must be done rigid and carefully, so that in the end the morphological (physical) characteristic of the coffee beans is affected as little as possible.

The drying process is one of the main post-harvest procedures for obtaining good quality coffee. Drying on the terrace allows the beans harvested with a very high initial humidity, ranging from 
$30.0 \%$ to $65.0 \%$ - depending on the maturation stage, to lose water to the environment through evaporation, aiming to achieve a suitable percentage of conservation, from $11.0 \%$ to $12.5 \%$ of humidity (BORÉM, 2008).

As Carvalho (1997) addresses in his study, the coffee quality depends on several factors and processes, such as crop management, pre-and post-harvest, which are essential to achieve a good characteristic for the beans.

According to the same author, artificial drying in terraces is the most used process by producers because it has a lower implantation cost compared to mechanical dryers, but coffee is exposed to climatic factors.

According to the study presented by the authors Santos and Reinato (2017) and Reinato (2006), terraces of asphalt mud and earth present mostly inferior beverages, such as Rio and Riada, whereas the cement and suspended terraces presented coffee beverages with superior qualities, mostly hard drink.

The suspended terrace has an installation price higher than the others, around $\mathrm{R} \$ 38.54$ per square meter, and lower durability, whereas the reinforced concrete has a price of $\mathrm{R} \$ 22.30$ per square meter, also presenting higher durability. The ground soil terrace has a low starting price of around $\mathrm{R} \$ 2.70$ per square meter, but as shown above, it has very low quality, when compared with the others, according to the study presented by Santos (2017).

In the patio made of porous concrete blocks, due to the rainwater infiltration process, it is expected that the humidity on the surface will be reduced and quickly dispersed to the environment, not being transferred to the grain, providing a product of better quality. The possibility of covering the patio for coffee drying combined with the rainwater infiltration for use on the property makes it interesting to use this material in the patio building.

Nowadays, the occurrence of long periods of drought, which are increasingly frequent, reinforces the need to capture and store water. When it comes to the rural environment, water has several usages, such as irrigation, cleaning the property, maintaining herds, and others.

The planet has undergone significant changes in the climate. Salati, Santos, and Nobres (2004) claim that "global warming will soon promote more extreme climate scenarios, with droughts, floods, and heatwaves becoming more frequent". Water is an essential natural resource for sustaining life and the environment. In this sense, all actions aimed at capturing and storing water in rural properties are extremely necessary and important.

In most of the coffee-producing rural properties, large areas are reserved for the drying process, the terraces for coffee drying. These areas are idle most of the time, and they are used only during the coffee harvest period. They could be used in other ways, such as rainwater infiltration, as long as it has been designed for this function. Therefore, there is the possibility of building these terraces with porous concrete paving blocks, which, besides removing moisture from coffee beans, will promote the rainwater infiltration that can be stored and used for non-potable purposes, such as cleaning the yard, corral, coffee washing, and even for irrigation, thus saving drinking water.

Rainwater harvesting occurs by the water infiltration through the pores of the porous concrete being collected by drainpipes and conducted to a storage reservoir. To increase the efficiency of the drainage system and avoid significant losses to the soil, the use of a waterproof plastic blanket is recommended.

Porous or permeable concrete has emerged as a solution in the United States of America in urban drainage, allowing water to infiltrate, reducing runoff. This fact occurs because the concrete presents interconnected empty spaces, as mentioned by Polastre and Silva (2006). Its durability varies from 20 to 40 years, depending on constant repair maintenance, since it is common to block 
the empty spaces by earth particles and chemical elements dispersed in the environment, such as sulfates, besides its natural degradation (POLASTRE; SILVA, 2006).

Regarding the load-bearing capacity, porous concrete has a lower resistance than conventional concrete, with variations between $3 \mathrm{MPa}$ and $30 \mathrm{MPa}$ depending on the material used. Reinforced concrete has a resistance that can reach up to $60 \mathrm{MPa}(\mathrm{ACl}-522,2010)$.

The concrete permeability varies according to the density of the mixture. The larger the void spaces, the higher the absorption (KIM; LEE, 2010). In this context, tests carried out by Federal University of Rio Grande do Sul - UFRS researchers presented a result of permeability of $0.3 \mathrm{~cm} \mathrm{~s}^{-1}$ for $1: 3$ and $0.5 \mathrm{~cm} \mathrm{~s}^{-1}$ for $1: 4$, demonstrating that the porous concrete permeability is sufficient to capture rainwater since absorption can reach up to $5 \mathrm{~mm} / \mathrm{s}$ according to the test above (IBRACON, 2014).

Based on the above considerations, this study aims to analyze the feasibility of implementing a terrace for drying natural coffee, using porous concrete blocks as a covering and its influence on the final quality of the coffee drink. The potential for rainwater infiltration and the costs of implementing the terrace covered with porous blocks were also evaluated.

\section{Material and methods}

\section{Characterization of the study area}

The experiment was carried out in the city of Cambuquira, located in the south of the state of Minas Gerais, whose economy comes from agriculture, livestock, and tourism. According to the Köppen and Geiger classification, the climate is classified as Cwa, with an average temperature of $19.5^{\circ} \mathrm{C}$ and total annual precipitation of $1,470 \mathrm{~mm}$ (Climate-Data.org, 2012).

\section{Construction of porous concrete paving blocks}

In the construction of the porous concrete paving block, 270 liters of gravel number 1 were used in dry conditions mixed with 3.8 cans of 18 liters of cement, adding a quantity of 33 liters of water, masonry equipment (hoe, bucket, and a trowel).

Initially, the gravel was mixed with the cement until it was homogeneous, and then 33 liters of water were added, making a new mixture until a uniform mass with an appearance similar to the concrete used in civil construction was obtained. After that process, the obtained mass was transported in buckets and placed in frames of $50 \mathrm{~cm} \times 50 \mathrm{~cm} \times 10 \mathrm{~cm}$ totaling ten blocks, which were used in the experiment assembly.

Figure 1 - A - Wooden frames used for the construction of the blocks. B - Finished porous cement block.

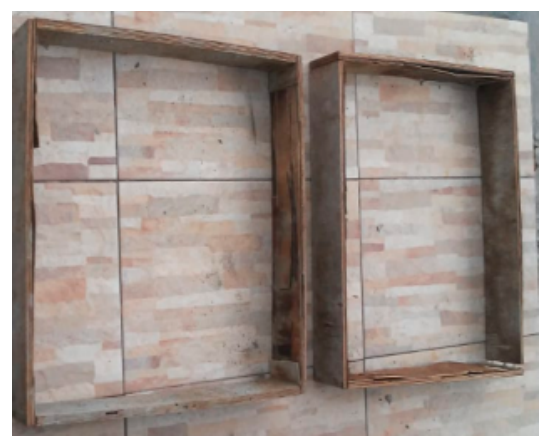

A

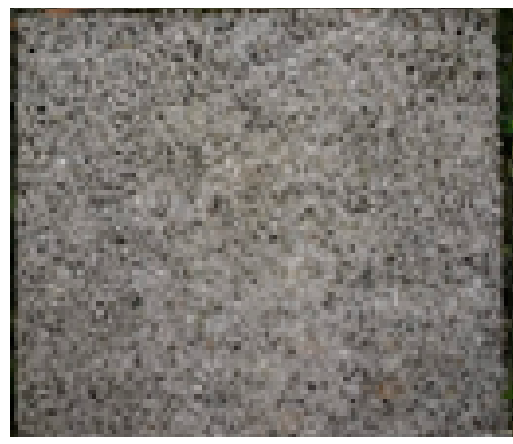

B

Source: Authors' elaboration (2019). 


\section{Experiment Assembly and Conduction}

For the experiment, cherry coffee was used. The experiment was carried out in a randomized block design (RBB) with 2 treatments and ten repetitions each, with a total of 20 plots. The treatments consisted of the disposition of cherry coffee in two types of terraces, ground soil and porous concrete, being distributed a $4 \mathrm{~cm}$ layer of cherry coffee.

The variables were subjected to analysis of variance, and the significant ones at the level of $5 \%$ probability were subjected to the Tukey test. Statistical analyzes were performed using the Sisvar software (FERREIRA, 2011).

\section{Evaluation of the presence of defects and the coffee drink quality}

The classification of defects is made in a 300-gram sample of raw dry coffee beans, and it is counted in the sample for classification following the Normative Instruction n. 8 from 2003, which has a rating scale of two to eight respectively and it will be separated according to the defects. Consequently, to rate the defect and remove the impurities and unusual matter present in the sample and then weight on a digital scale, the defect with higher gravity in the sample prevails as black partial black, sour, immature, and broken grain (BRASIL, 2003).

The conventional "coffee cupping" was carried out by an experienced taster, following the procedures required by the Ministry of Agriculture, Livestock and Supply. The analyzes were carried out at Cooperative of Coffee Growers in the Varginha Zone (Minasul), in the city of Cambuquira/MG.

According to normative n. 8 of the Ministry of Agriculture, Livestock and Supply (BRASIL, 2003), there are currently seven quality scale of the coffee drink, which are Rio Zona, Rio, Riado, Hard, Just Soft, Strictly Soft, and Soft, the Strictly Soft being the one with the best characteristics and all the requirements for aroma and "soft" flavor.

\section{Water infiltration evaluation in porous concrete paving blocks and the potential for rainwater infiltration}

To carry out the infiltration test on porous concrete paving blocks, the methodology described in NBR 16416 - Permeable Concrete Pavements (ABNT, 2015) was used.

To start the infiltration test, the porous concrete blocks were pre-wetted, pouring 3.6 liters of water into the cylinder, and registering the time taken for all the water to infiltrate. For pre-wetting times of less than 30 seconds, 18 liters of water were used to perform the test, and the time was measured again. For times higher than 30 seconds in the pre-wetting stage, the amount of water required for the test was 3.6 liters. For both the pre-wetting stage and the performance of the test, it was sought to maintain a constant flow of water inside the cylinder so that a blade between $10 \mathrm{~mm}$ and $15 \mathrm{~mm}$ was maintained during the procedure. To simulate the impact of moisture present in the porous concrete paving blocks in the infiltration process, a $20 \mathrm{~mm}$ rain was simulated by applying 5 liters of water over each block; after 24 hours, the infiltration test was carried out.

The infiltration test was carried out on all porous concrete paving blocks. For this purpose, a cylinder of $30 \mathrm{~cm}$ in diameter with a height of $50 \mathrm{~cm}$ was placed in the center of each porous concrete paving block, and the lower edges rejoined with cement to guarantee the use of the internal area of the cylinder only. It was calculated the time that every volume of water took to completely infiltrate the block's surface, allowing the calculation of the block's permeability.

The following equation used by Gonçalves and Bandeira (2017) was applied in this study: 


$$
K=\frac{C \cdot m}{\left(d^{2} \cdot t\right)}
$$

At which:

$\mathrm{K}$ : is the infiltration rate given in $\mathrm{mm} \mathrm{h}^{-1}$

$\mathrm{m}$ : infiltrated water mass, expressed in $\mathrm{kg}$

$\mathrm{d}$ : internal diameter of the cylinder, expressed in $\mathrm{mm}$

t: time taken by the water to infiltrate, expressed in seconds

C: SI unit conversion factor, with a value of $4,583,666,000$

To evaluate the potential rainwater infiltration in the study area, the average annual precipitation was calculated based on a historical series of daily precipitation between 1988 and 2018, from the weather station known as Fazenda Juca Casimiro, code 02145008 , located in the city of Cambuquira, under the responsibility of IGAM-MG, coordinates S $21^{\circ} 52$ '27.12" and W $45^{\circ} 15^{\prime} 29.88^{\prime \prime}$ " and altitude of $875 \mathrm{~m}$.

\section{Results and discussions}

Table 1 shows the cost of producing the porous concrete paving blocks.

Table 1 - Values spent in ten porous concrete paving blocks.

\begin{tabular}{ccc}
\hline Components & Unit & Values \\
\hline Gravel 1 & 15.0 cans & 75.00 \\
Cement & 3.8 cans & 30.6 \\
Water & 33.0 liters & 0.0 \\
Total & & 105.6 \\
\hline
\end{tabular}

Source: Gomes, J. P. J. (2019).

The cost of implementation for the porous concrete paving blocks $10 \mathrm{~cm}$ high in the patio building was equivalent to $\mathrm{R} \$ 42.24$ per $\mathrm{m}^{2}$ in the year 2019 . When compared to the costs of setting up a ground soil terrace, this amount is approximately 11 times higher. According to Santos and Reinato (2017), who evaluated several types of terraces, they concluded that the cost of implementing the ground soil terrace at that time was $\mathrm{R} \$ 2.70$ per $\mathrm{m}^{2}$, equivalent to $6.4 \%$ of the cost of implementing the terrace with porous blocks. In 2019, it would be a value of approximately $\mathrm{R} \$ 3.73$ per $\mathrm{m}^{2}$, and this value will be considered in the following calculations.

Although the implantation cost is very high concerning the ground soil terrace, it has the advantage of the possibility of rainwater infiltration, contributing to the environmental sustainability of this resource.

\section{Classification of beverage quality and analysis of physical coffee bean defects}

Table 2 shows the statistical results of coffee beans quality and defects for the two types of drying terraces. 
Table 2 - Beverage quality and types of defects in coffee beans subjected to drying in a porous block and drying in-ground soil terrace.

\begin{tabular}{ccc}
\hline Variable & Porous block & Drying in-groundsoil terrace \\
\hline Drink quality & $4.0 \mathrm{a}$ & $2.8 \mathrm{~b}$ \\
Defect types & $3.4 \mathrm{~b}$ & $5.9 \mathrm{a}$ \\
\hline
\end{tabular}

Averages followed by the same letter, on the line, do not differ statistically through the Tukey test, at $5 \%$ probability.

Source: Authors' elaboration (2019).

As shown in Table 2, the ground soil terrace provides lower quality in the coffee drink, as a result of several factors interaction such as the undesirable fermentation process during the drying process. Similar results were also observed by Santos and Reinato (2017).

The best drink was obtained when the coffee beans were dried on the porous concrete paving terrace, a fact that may encourage the implementation of this type of terrace by coffee producers.

Most of the ground soil terrace provided coffee with Riado or Rio drink, that is, grade 2 to 3 , except one sample classified as Duro, grade 4. Coffee dried on the porous concrete block terrace produced, in its majority, hard drink coffees, with grade 4, except for two samples that presented drink type Riado, grade 3 and Soft, grade 5.

Most of the dried coffee on a ground soil terrace generated drink of low appreciation value from customers, on average $2.8 \mathrm{~b}$ and, consequently, a lower market value, concluding that the coffee beans dried on a porous concrete block terrace produced a better quality drink, presenting a statistically better result, an average of 4.0a. Similar results were obtained by Reinato (2006) concerning ground soil terrace, where he concluded that that is the least viable for the drying process.

Regarding the defects found, according to Table 2, the result provided by the classification in relation to the defects of each sample was given by the 'type' that varies from 2 to 8 , being classified as 2 the ones of least defects, and as 8 the one of highest number of defects (CARVALHO, 1997).

Coffee beans dried on a ground soil terrace had defects ranging from 5 to 7 , with an average of 5.9a. On the other hand, the ones dried on a porous concrete block patio presented defects between 3 and 4 , with an average of $3.4 \mathrm{~b}$.

Based on these results, it can be concluded that the ground soil terrace has a higher number of defects than the porous concrete block terrace. According to Reinato (2006), the fact that the ground soil terrace has higher numbers of defects is due to the sanitary, higher incidence of fungi and bacteria that deteriorate the quality of the coffee bean, issues that came up at the time of drying, favoring the appearance of burnt and dark grains. Therefore, it is evident that the ground soil terrace does not favor the final quality of the product, generating a devaluation in the price. In this sense, the porous concrete block terrace compared to the ground soil terrace showed better results statically. However, even presenting the best results, the porous concrete block terrace did not obtain the best score for such classification, which is type 2 . This may be due to the number of broken grains, due to the terrace that has a rougher surface than the other ones.

\section{Permeability analysis of the porous concrete block}

The infiltration test was carried out on all the porous concrete paving blocks used, showing the capacity of water infiltration that passes through the blocks per unit of time. 
The results showed that the water infiltration capacity of the porous concrete paving blocks varied from 3,637.8 $\mathrm{mm} \mathrm{h}^{-1}$ to $3,960.0 \mathrm{~mm} \mathrm{~h}^{-1}$, with an average value of 3,842.8 $\mathrm{mm} \mathrm{h}^{-1}$ representing a potential volume of rainwater infiltration equal to $3,842.8 \mathrm{I} / \mathrm{m}^{2} \mathrm{~h}^{-1}$.

The result above demonstrates the excellent permeability of the porous concrete block obtained with a 1:3 line, a cemented part for three parts of number 1 gravel, this line and line 1:4 are the most recommended when the objective is the infiltration of water, according to Kim and Lee (2010).

\section{Rainwater infiltration potential by the porous concrete paving block terrace in the city of Cambuquira - MG}

Based on the historical series of the meteorological station precipitation known as Fazenda Juca Casimiro, in the city of Cambuquira/MG, the average annual precipitation for the municipality was $1,470.0 \mathrm{~mm}$.

According to Araújo, Tucci and Goldefum (2000), the effective infiltration of water that crosses the porous concrete block through the drainage system is $40 \%$ if the drains are placed on the ground, that is, without the blanket plastic. The remaining $60 \%$ is lost due to evaporation, percolation in the soil, and the non-infiltration of the drainage system.

In this way, considering that a plastic blanket was not used below the porous concrete terrace, of the total precipitated annually, $1,470.0 \mathrm{~mm}$, it would be possible to infiltrate $588 \mathrm{~mm}$ year $^{1}$. Considering a terrace for drying coffee with an area of $100 \mathrm{~m}^{2}$, it would be possible to capture and store $58.8 \mathrm{~m}^{3}$ year ${ }^{1}$. This volume would be used for non-potable purposes, requiring no treatment, reducing the consumption of drinking water for less noble purposes.

\section{Analysis of the economic feasibility of implementing a porous concrete block paving terrace}

Considering a distribution of 50 liters of cherry coffee per square meter of the terrace and one bag of coffee corresponds to 500 liters, $10 \mathrm{~m}^{2}$ of the terrace would be needed for each bag of coffee beans. For the analysis of the porous concrete paving blocks terrace implementing feasibility, the costs for the porous concrete blocks production, the drainage system, and a reservoir with a water storage capacity of $20 \mathrm{~m}^{3}$ were considered. The quotations for coffee bags type 4 hard drink and type 6 Riada drink were obtained from the Coffee Growers Cooperative of the Varginha Zone (Minasul), in November 2019, representing the Southern region of the State of Minas Gerais. The average values found were, respectively, $\mathrm{R} \$ 505.00$ and $\mathrm{R} \$ 418.00$ for bags of coffee type 4 hard drink and type 6 Riada drink. In this way, it was possible to evaluate the expected gain per square meter in each type of terrace for drying coffee.

In the ground soil terrace, the predominant type of drink was the Riada drink, which provides an approximate yield of $\mathrm{R} \$ 41.80 \mathrm{~m}^{2}$, whereas the dried coffee in the porous concrete block paving terrace generates gains of $R \$ 50.50 \mathrm{~m}^{2}$, that is, a profit of $R \$ 8.70 \mathrm{~m}^{2}$ concerning coffee dried on a ground soil terrace.

For a $100 \mathrm{~m}^{2}$ terrace, $\mathrm{R} \$ 4,224.00$ would be spent for the implementation of the porous concrete block terrace, plus $\mathrm{R} \$ 600.00$ for the drainage system, and $\mathrm{R} \$ 1,000.00$ for the acquisition of a polyethylene reservoir to store infiltrated water, with a capacity of $20 \mathrm{~m}^{3}$, totaling an implementation cost of $\mathrm{R} \$ 5,824.00$. For the ground soil terrace, the costs would be $\mathrm{R} \$ 373.00$.

Considering a useful life of 10 years, since the necessary maintenance is carried out, the costs of patios implementation would be paid in the first, for the ground soil terrace and from the second year onwards, for the porous concrete block paving terrace, that is, for the rest of the useful life period, 
the producer would have $100 \%$ profit. For the ground soil terrace, the gain in the period of its useful life is $R \$ 41,427.00$. As for the porous concrete block terrace, the gain is equal to $R \$ 44,676.00$, a profit of approximately $8 \%$ compared to ground soil terrace, equivalent to $R \$ 3,249.00$.

Based on the potential for water infiltration by the porous concrete paving block terrace for the city of Cambuquira equal to $58.8 \mathrm{~m}^{3}$ year ${ }^{-1}$ and considering a value of $\mathrm{R} \$ 5.00$ per $\mathrm{m}^{3}$ of treated water, which would be used for non-potable purposes (environmentally incorrect) that will no longer be paid, the profit concerning the volume raised would be $R \$ 2,940.00$ in 10 years, totaling in the end a profit for the porous concrete paving block terrace of $R \$ 47,616.00$, corresponding to $R \$$ $6,189.00$ above the profit provided by the ground soil terrace, approximately $15 \%$.

\section{Conclusion}

The cherry coffee drying process on a porous concrete block terrace provided better quality for both drinking and reducing the number of defects in the beans.

The construction of the porous concrete block terrace is economically viable compared to the ground soil terrace.

A potential for rainwater infiltration in the porous concrete block area of approximately $3.8 \mathrm{~m}^{3} /$ $\mathrm{m}^{2} \cdot \mathrm{h}^{-1}$ was identified. In the city of Cambuquira/MG, the volume with the potential to be infiltrated and stored is around $58.8 \mathrm{~m}^{3}$ year ${ }^{1}$.

\section{Viabilidade de terreiro revestido com blocos de concreto porosos para secagem do grão de café}

\section{Resumo}

O sucesso da atividade cafeeira depende do processo de secagem dos grãos, visto que influencia grandemente a qualidade físico-química do café, gerando bebidas de boa ou má qualidade. Neste sentido, o tipo de terreiro tem grande influência na qualidade final do produto. Portanto, neste trabalho foram avaliados terreiros de terra batida e bloco de concreto poroso, sendo o experimento conduzido no município de Cambuquira/MG. Para tanto, foram construídos blocos de concreto porosos e de terra batida com as dimensões de $50 \times 50 \times 10 \mathrm{~cm}$, totalizando 10 blocos de cada tipo de terreiro. 0 delineamento experimental foi em blocos casualidades (DBC), sendo utilizado o café cereja, com 10 repetições, totalizando 20 parcelas. Para a avaliação da capacidade de infiltração de água no bloco de concreto poroso, utilizou-se de um cilindro de $30 \mathrm{~cm}$ de diâmetro colocado no centro do bloco de concreto poroso, com as bordas inferiores rejuntadas com cimento para garantir a utilização somente da área interna do cilindro. O processo de secagem do café em terreiro de bloco de concreto poroso proporcionou melhor qualidade tanto na bebida quanto na redução do número de defeitos nos grãos. No município de Cambuquira, o potencial de infiltração e armazenamento de água pluvial é de 58,8 m³/ano. Considerando um horizonte de 10 anos (vida útil), a construção do terreiro de bloco de concreto poroso é economicamente viável em relação ao terreiro de terra batida, proporcionando ganhos de até $15 \%$.

Palavras-chave: Qualidade do café. Infiltração da água pluvial. Água da chuva. 


\section{References}

ASSOCIAÇÃO BRASILEIRA DE NORMAS TÉCNICAS. 16416: Pavimentos permeáveis - requisitos e procedimentos. Rio de Janeiro, 2015. 25 p.

ACl - 522 - Cartilha da Associação Brasileira de Cimento Portland. Specification for Pervious Concrete Pavement. American Concrete Institute, 2010.

ARAÚJO, P. R., TUCCI, C. E. M., GOLDEFUM J. A. Avaliação da eficiência dos pavimentos permeáveis na redução do escoamento superficial. Instituto de Pesquisas Hidráulicas da UFRG. Porto Alegre, "RBRH: Revista Brasileira de Recursos Hídricos, v. 5, n. 3, jul/set 2000, 21-29. Available at: http://rhama.com.br/blog/wp-content/uploads/2017/01/avaliacao-da-eficiencia-dos-pavimentos-nareducao-de-escoamento-superficial.pdf. Access on: 25 jun. 2020.

BORÉM, F. M. Cafeicultura empresarial: produtividade e qualidade. Pós Colheita do café, Lavras: UFLA/FAEPE, 2004. 103 p. (Textos Acadêmicos).

BORÉM, F. M.; CORADI, P. C.; SAATH, R.; OLIVEIRA, J. A. Qualidade do café natural e despolpado após secagem em terreiro e com altas temperaturas. Ciência e Agrotecnologia, Lavras, v. 32, n. 5, p. 1605-1615, set./out. 2008. Available at: http://www.scielo.br/scielo.php?script=sci_ arttext\&pid=S1413-70542008000500038\&lng=en\&nrm=iso. Access on: 25 jun. 2020.

BRASIL, Ministério da agricultura, pecuária e abastecimento. Regulamento técnico de identidade e de qualidade para a classificação do café beneficiado e de café verde. Instrução Normativa n. 8 de 11/06/03. Brasília, 2003.

CARVALHO, V. D. Qualidade do Café. Curso de Especialização Pós-Graduação "Lato-Senso" por Tutoria à Distância-Cafeicultura Empresarial: Produtividade e Qualidade. Lavras: UFLA/FAEPE, 1997. v. 2, $73 \mathrm{p}$.

CLIMATE-DATA, Dados Climáticos. 2012. Available at: www.climate-data.org/america-do-sul/brasil/ minas-gerais/cambuquira-176308/. Access on: 8 jun. 2019.

CONAB - COMPANHIA NACIONAL DE ABASTECIMENTO. 2018. Available at: www.conab.gov. br/ultimas-noticias/2626-producao-do-cafe-em-2018-e-recorde-e-supera-61-milhoes-de-sacas. Access on: 25 maio 2019.

COSTE, R. Les caféiers et les cafés dans lê monde. Paris: Larose, 1955. 365 p.

FERNANDES, S. M.; PEREIRA, R. G. F. A.; PINTO, N. A. V. D.; NERY, M. C.; PÁDUA, F. R. M. de. Constituintes químicos e teor de extrato aquoso de cafés arábica (Coffea arabica L.) e conilon (Coffea canephora Pierre) torrados. Ciência e Agrotecnologia, v. 27, n. 5, p. 1076-1081, 2003. Available at: http://www.scielo.br/scielo.php?script=sci_arttext\&pid=S1413-70542003000500015\&lng=en\&n rm=iso. Access on: 25 jun. 2020. 
FERREIRA, D. F. SISVAR: um sistema computacional de análise estatística. Ciência e Agrotecnologia, v. 35, n. 6, nov./dez. 2011. Available at: http://www.scielo.br/scielo.php?script=sci_arttext\&pid=S1413$70542011000600001 \& \operatorname{lng}=$ en\&nrm=iso. Access on: 25 jun. 2020.

GONÇALVES, C.M.; BANDEIRA, R. A.M. Análise da capacidade de infiltração em pavimento permeável de bloco de concreto unidirecionalmente articulado. Revista Transporte, v. 25 n. 22017.

IBRACON - Instituto Brasileiro do Concreto. 2014 Available at: www.ibracon.org.br. Access on: 23 maio 2019.

KIM, H. K.; LEE, H. K. Influence of cement flow and aggregate type on the mechanical and acoustic characteristics of porous concrete. Elsevier Journal. Applied Acoustics, 2010.

MARQUES, E. R.; BORÉM, F. M.; PEREIRA, R. G. F. A.; BIAGGIONI, M. A. M. Eficácia do teste de acidez graxa na avaliação da qualidade do café arábica (Coffea arabica L.) submetido a diferentes períodos e temperaturas de secagem. Revista Ciência e Agrotecnologia, Lavras, v. 32, n. 5, p. 1557-1562, 2008. Available at: http://www.scielo.br/scielo.php?script=sci_arttext\&pid=S141370542008000500030\&lng=en\&nrm=iso. Access on: 25 jun. 2020.

MOURA, S. C. S. R. de; GERMER, S. P. M.; ANJOS, V. D. de A.; MORI, E. E. M.; MATTOSO, L. H. C.; FIRMINO, A.; NASCIMENTO, C. J. F. Avaliações físicas, químicas e sensoriais de blends de café arábica com café canephora (Robusta). Brazilian Journal of Food Technology, Campinas, v. 10, n. 04, p. 271-277, out./dez. 2007.

PAUlino, A. J.; MATIELlO, J. B.; PAULINI, A. E.; BRAGANÇA, J. B. Cultura do café conilon (instruções técnicas sobre a cultura de café no Brasil). Rio de Janeiro: IBC/DIPRO, 1987. 43 p.

POLASTRE, B.; SILVA, L. D. Concreto permeável. Universidade de São Paulo, 2006. Available at: http://www.fau.usp.br/arquivos/disciplinas/au/aut0221/Trabalhos\%20Finais\%202006/Co creto\%20 perme\%C3\%A1vel.pdf. Access on: $10 \mathrm{dez} .2019$.

REINATO, C. H. R. Secagem e armazenamento do café: aspectos qualitativos e sanitários. 2006. 111 p. Tese (Doutorado em Ciências dos Alimentos) - Universidade Federal de Lavras, Lavras 2006.

REINATO, C. H. R.; BORÉM, F. M.; SILVA, P.; ABRAHÃO, E. J. Qualidade da bebida dos cafés descascado, cereja, bóia e roça secados em terreiros de terra e lama asfáltica. In: Congresso Brasileiro de Pesquisas Cafeeiras, 31., 2005, Guarapari.

SALATI, E; SANTOS, A. A. dos NOBRES, C. As mudanças climáticas globais e seus efeitos nos ecossistemas brasileiros. (2004). Available at: http://www.comciencia.br/reportagens/ clima/clima14.htm. Access on: 25 jun. 2019.

SANTOS, O. L.; REINATO, C. H. R.; JUNQUEIRA, J. D.; FRANCO, E. L.; SOUZA, C. W. A.; REZENDE, A. N. Custo-benefício da secagem de café em diferentes tipos de terreiro. Revista Agrogeoambiental, Pouso Alegre v. 9, n. 4, dez. 2017. Available at: https://agrogeoambiental.ifsuldeminas.edu.br/index. php/Agrogeoambiental/article/view/966. Access on: 25 jun. 2020. 
SILVA, J. S.; LACERDA FILHO, A. F. Construção de secador para produtos agrícolas. Viçosa, MG: Universidade Federal de Viçosa, 1984. 17 p. (UFV. Informe técnico, 41).

VIANA, A. S.; MATIELLO, J. B.; SOUZA, T. Estudo do efeito de revestimento de terreiros no tempo de seca e na qualidade do café. In: CONGRESSO BRASILEIRO DE PESQUISAS CAFEEIRAS, 28., 2002, Caxambu. Anais... Caxambu, 2002. p. 53-56.

Received: March 16, 2020

Accepted: June 25, 2020 